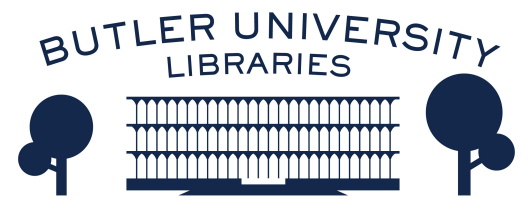

Journal of Hindu-Christian Studies

Volume 31 Celebrating Rāmānuja at 1000: The

Heritage and Promise of the Study of Rāmānuja

in a Christian-Hindu Comparative Theology

Article 17

2018

\title{
Rudolf Otto's Encounter with Rāmānuja as a Model for Comparative Theology
}

Hugh Nicholson

Loyola University of Chicago

Follow this and additional works at: https://digitalcommons.butler.edu/jhcs

\section{Recommended Citation}

Nicholson, Hugh (2018) "Rudolf Otto's Encounter with Rāmānuja as a Model for Comparative Theology," Journal of Hindu-Christian Studies: Vol. 31, Article 17.

Available at: https://doi.org/10.7825/2164-6279.1694

The Journal of Hindu-Christian Studies is a publication of the Society for Hindu-Christian Studies. The digital version is made available by Digital Commons @ Butler University. For questions about the Journal or the Society, please contact cbauman@butler.edu. For more information about Digital Commons @ Butler University, please contact digitalscholarship@butler.edu. 


\title{
Rudolf Otto's Encounter with Rāmānuja as a Model for Comparative Theology
}

\author{
Hugh Nicholson \\ Loyola University of Chicago
}

\begin{abstract}
Among his more noteworthy achievements, Rudolf Otto introduced Vaiṣnava theism, Rāmānuja's Viśiștāâdvaita in particular, to a broader theological audience. In this paper, I argue that despite the wellknown shortcomings of Otto's comparative work, in particular, his tendency to essentialize the compared traditions and his presumption of Christian superiority, Otto's encounter with Rāmānuja and Vaiṣnavism nevertheless anticipates some of the characteristic features of the contemporary practice of Comparative Theology. The article describes how Otto's work on Vaiṣnavism exemplifies two such features of the new Comparative Theology in particular. The first of these is this discipline's concern with problematizing the often invidious representations of non-Christian traditions that have historically sustained notions of Christian uniqueness. The second is its skillful use of comparison to foreground features of the home tradition that might otherwise escape notice.

As is well known, the German Lutheran theologian Rudolf Otto undertook a serious study of Sanskrit and the theological
\end{abstract}

traditions of Hinduism in the second half of his academic career. Arguably his greatest Indological achievement was introducing Vaiṣnava theism, Rāmānuja's Viśișțādvaita in particular, to a broader theological audience. ${ }^{1}$ In this short paper I would like to argue that not only does Otto's encounter with Rāmānuja and Vaiṣnavism represent a significant moment in the reception history of Indian religious thought in the West, but it also exemplifies some of the characteristic features of the contemporary practice of Comparative Theology. Indeed, as I have argued elsewhere, Otto was a comparative theologian avant la lettre. ${ }^{2}$

There are two characteristic features of the new Comparative Theology in particular that I wish to highlight, the first of which is critical, the second constructive. The first of these is the discipline's concern with problematizing the often invidious representations of non-Christian traditions that have historically sustained notions of Christian uniqueness. The second, more constructive aspect of Comparative Theology is its skillful use of comparison to foreground features of the home tradition that might

\footnotetext{
Hugh Nicholson is Associate Professor at Loyola Chicago University. He received his MA in Religion from Yale Divinity School and his Ph.D. (Systematic theology) from Boston College. He specializes in comparative (interreligious) theology with a focus on the Christian, Hindu, and Buddhist traditions. His recent books are The Spirit of Contradiction in Buddhism and Christianity (2016) and Comparative Theology and the Problem of Religious Rivalry (2011), published by Oxford University Press.
} 
otherwise escape notice. I shall discuss each of these in turn with reference to Otto's encounter with Rāmānuja and the ŚrīVaiṣnava tradition.

\section{I.}

That the works of Christian missiological and apologetic literature often contain gross misrepresentations of the teachings of nonChristian faiths is well known. And yet the construction of a "projected other" to sustain notions of Christian uniqueness need not rely on gross mischaracterizations of nonChristian teachings. Biases can creep in, even without the theologian being fully aware of them, in the seemingly innocent, and indeed unavoidable, selection of voices within a religious tradition to represent that tradition more broadly. A textbook example of the way in which an act of selection can misrepresent a tradition is the valorization of the Nondualist Vedānta of Śankara as the epitome of Hindu religious thought in the orientalist construction of Hinduism. For a complex set of reasons, the Advaita Vedānta doctrines of the illusory nature of the phenomenal world and the complete renunciation of action as the path to liberation held particular interest for European students of Indian religion. As critics of "orientalism" have long noted, the notion that these Advaita doctrines somehow represent the putative essence of Hinduism served as a foil for the virtues that were taken to define European culture, virtues such as scientific rationality, a spirit of industriousness, and an active, ethical concern for the welfare of others. ${ }^{3}$ Apart from the fact that Sankara's thought is far more subtle and complex than the world-negating quietism that is commonly attributed to him, it is entirely misleading to use Śankara as an exemplar of the religious thought of India. A perusal of the various works in which Otto introduces Rāmānuja and Vaiṣnavism to a
Christian audience carries a salutary reminder of just how pervasive this misconception of Hinduism was.

Otto dramatizes the challenge Rāmānuja presents to the orientalist picture of Hinduism in a moving account of his visit with a Vaiṣnava gosvāmin in Benares. Otto and his English guide are surprised to learn that the gosvāmin maintains that the world is real, not illusory. "But do not the sages of India teach," the two Europeans object, "that the world is appearance, devoid of essence and truth?" "So teaches Śankara," replies the gosvāmin, "But Sankara is not 'the sages of India'." " So obvious is this point to contemporary scholars of Hinduism that we might suspect that Otto exaggerates the shock produced by this discovery for rhetorical effect. Nevertheless his depiction does accurately convey the prevailing conception of Indian religion in the West during the first decades of the twentieth century.

Rāmānuja's principal significance for Otto was as Śankara's great adversary, a role no more clearly evident than in the former's polemical commentary on the opening verse of the Brahma-Sutra. ${ }^{5}$ The dispute between Śankara and Rāmānuja takes on almost mythic proportions in Otto's rendering. The two adversaries symbolize the perennial antagonism, reenacted throughout the history of religions, between, on the one hand, an austere, world-denying mysticism centered on an impersonal and incomprehensible Absolute and, on the other, faith in the living, personal God of religious devotion. ${ }^{6}$

As mentioned above, Otto's achievement in broadening the prevailing conception of Indian religious thought - at least to German speaking audiences - to include a full-fledged devotional theism provides a model for today's comparative theology. But the kind of challenge exemplified by Otto's retrieval of 
Rāmānuja is only a beginning. Contemporary comparative theologians have extended this critical aspect of Otto's project by deliberately selecting peripheral and indeed marginalized voices within the compared traditions as a way of proactively unseating hegemonies held in place by the inertia of tradition. As Michelle Voss Roberts eloquently argues, nowhere is this critical task more urgent than in the retrieval of women's voices in the compared traditions, effectively excluded, even if unintentionally, by a preoccupation with canonical texts. $^{7}$

\section{II.}

Although Rāmānuja is important to Otto as a figure challenging Śankkara's hegemony in the Western conception of Hinduism, Otto's primary interest lies less in Rāmānuja's theology per se than in later developments in Rāmānuja's Śrī-Vaiṣnava tradition that more closely resemble the sola gratia doctrine of Otto's Protestant faith. In keeping with Rāmānuja's rejection of Śankara's doctrine of complete renunciation, Rāmānuja's concept of bhakti presupposes a continuing commitment to ritual practice or, expressed in Otto's Protestant idiom, "works." Out of this integrative concept of bhakti later Vaiṣnava theologians will distill a radical concept of surrender or prapatti, which they will henceforth contrast with what will appear in retrospect as a rather staid and dispassionate concept of bhakti. ${ }^{8}$ Otto cannot resist seeing in this radicalization of the concepts of devotion and grace a parallel with Luther's doctrine of justification by faith alone.

When we widen our focus from Rāmānuja's authored works to those of the larger Vaiṣnava movement of which he was a part, the second feature of Comparative Theology exemplified by Otto - namely, the use of comparison as a heuristic of theological discovery - comes clearly into view. Otto's use of comparison as an instrument of theological discernment occurs, perhaps unexpectedly, in the context of his unabashedly apologetic concern with demonstrating the superiority of the Christian religion. ${ }^{9}$ A favorite apologetic strategy of Otto's, found not only in his comparative theological study of Vaișnavism, India's Religion of Grace and Christianity Compared and Contrasted, but also in his earlier comparison of Śankara and Meister Eckhart, is to build a case for the superiority of Christianity - somewhat paradoxically -- on the basis of the closest of parallels. Otto's India's Religion of Grace is based on the striking resemblance between, on the one hand, the characteristically Protestant Christian doctrine of unmerited grace and, on the other, Vaișnava theologies of prapatti, particularly the most radical form of the Vaișnava doctrine of grace - the way of the cat - propounded by the southern, Tenkalai school of Śrī-Vaiṣnavism. The prapatti concept of Vaiṣnava theology presents a stark challenge to apologetic claims of Christian superiority based on the putative uniqueness of the doctrine of divine grace. ${ }^{10}$ And yet, for Otto, the discovery of this parallel does not lead to an abandonment of the apologetic project. Rather, it challenges the Christian apologist to work harder, to discern more precisely how the Christian doctrine of grace differs essentially from that of its Indian counterpart. ${ }^{11}$ For Otto, the comparison foregrounds the central place that the concept of holiness or sanctity has in the Christian concept of salvation. ${ }^{12}$ Otto does not claim that the concept of holiness, together with its associated concepts of redemption and sin, are absent in Hindu devotionalism. ${ }^{13}$ Nor, conversely, does he claim that the controlling idea of Rāmānuja's Vedānta, namely, the liberation from perishableness through communion with the imperishable, is lacking 
in Christianity. ${ }^{14}$ And yet comparison reveals the dominant and characteristic aspect of each form of devotionalism. Otto expresses this idea with his metaphor of the axis around which a physical body - here extended to the notion of a religion as a spiritual formation turns. Thus the axis of Christianity "is not atma-siddhi but the idea of the Holy." 15 The axis metaphor allows Otto acknowledge the presence of shared elements in the various religions while still retaining the apologetical notion of an essential or qualitative difference between them. ${ }^{16}$ Put differently, Otto uses the axis metaphor to counter the relativistic notion that the difference between Christianity and Hinduism is simply a matter of the degree of emphasis given to shared elements.

One can certainly take issue with the essentialist presuppositions of Otto's specific comparative judgments, as well as with his a priori presumption of Christian superiority. And yet, I would argue that his general method - using comparison not only to disabuse Christians of factually untenable claims of Christian uniqueness but also to fine-tune one's concept of Christian identity - remains valid. One sees this method on display, for example, in the case studies comprising Francis Clooney's exemplary book, Hindu God, Christian God. The main take-away of Clooney's study is that there are striking Hindu parallels for theological arguments for divine embodiment and revelation, for example - that are commonly assumed by Christians to be distinctively, if not uniquely, Christian. ${ }^{17}$ And yet, while Clooney's emphasis clearly falls on the first, critical aspect of Otto's method, he allows for the possibility of an apologetics, albeit one that is informed and respectful of the religious other, to be taken up on the other side of comparison. ${ }^{18}$
We can appreciate not only Otto's comparative theological method, but also the spirit of generosity and theological sensitivity that informs his theological judgments if we compare his work with that of scholars even a couple of generations after him. A good example of the latter, taken more or less at random, would be Adam Hohenberger's theological study of Rāmānuja, Rāmānuja: ein Philosoph indischer Gottesmystik, published in 1960. Hohenberger concludes a more or less descriptive presentation of Rāmānuja's teachings with a brief assessment of Rāmānuja's tradition entitled "Rāmānuja in Light of the Gospel." There one finds a set of traditional, indeed predictable, Christian apologetic judgments. The figure of Visnu, as evident particularly in his incarnation as the treacherous and cunning Krsna of the Mahabharata, reveals himself to be nothing more than the product of the human imagination. ${ }^{19}$ The wonders attributed to the Hindu deities like Visnu, Hohenberger declares, owe their origins to unbridled human fantasy. In stark contrast, the evangelists who recounted the miracles of Jesus were witnesses to actual historical realities. ${ }^{20}$ Hohenberger regards the later Vaișnava doctrine of prapatti to be unduly compromised by the doctrine of rebirth that underlies Hindu soteriology. And seemingly unable to believe that a radical doctrine of grace could be indigenous to India, he countenances Richard Garbe's dubious hypothesis that Rāmānuja's doctrine of grace resulted from historical contacts with early Nestorian Christians. ${ }^{21}$ Examples like Hohenberger's support Hans Rollmann's summary assessment of German language theological scholarship after Otto: "A quick glance at subsequent German scholarship reveals that the comparative theological task did not achieve Otto's standard again." 22 One 
would hope that things have changed since 1979 when Rollmannn wrote these words. Today's Comparative Theology has certainly surpassed Otto, both in the depth of its engagement with non-Christian traditions as well as in its capacity to question the essentialist presuppositions not only of Christian apologetics but also of earlier forms of Comparative Religion. And yet, in his

\section{Notes}

${ }^{1}$ Hans Rollmann, "Rudolf Otto and India," Religious Studies Review 5, no. 3 (1979): 199. DOI: https://doi.org/10.1111/j.17480922.1979.tb00216.x

${ }^{2}$ Hugh Nicholson, Comparative Theology and the Problem of Religious Rivalry (New York: Oxford University Press, 2011), xiv, 119-128. DOI: https://doi.org/10.1093/acprof:oso/978019977286 5.001 .0001

${ }^{3}$ See Ronald B. Inden, Imagining India (Bloomington, IN: Indiana University Press, 1990), esp. 105-108; Richard King, Orientalism and Religion (New York: Routledge, 1999), DOI: https://doi.org/10.4324/9780203006085, esp. 118142.

${ }^{4}$ Rudolf Otto, Visnu-Narayana: Texte zur indischen Gottesmystik (Jena, 1923), 2. Cf. also idem., Siddhanta des Ramanuja (Tübingen 1923), 1; India's Religion of Grace and Christianity Compared and Contrasted, trans. Frank Hugh Foster (New York: McMillan, 1930), 31-32.

${ }^{5}$ Otto, Siddhanta des Ramanuja, 2 ff., cf. John Carman, The Theology of Ramanuja (New Haven: Yale University Press, 1974), 200.

${ }^{6}$ Siddhanta des Ramanuja, 2.

${ }^{7}$ Michelle Voss Roberts, Dualities: A Theology of Difference (Louisville: Westminster/John Knox, 2010), 4-7; idem., "Gendering Comparative Theology," In The New Comparative Theology, commitment to the theological value of interreligious comparison and his sensitivity to the religious import of the Hindu traditions he studied, particularly when judged by the standards of his time, Otto set a standard for the contemporary comparative theologian.

Francis X. Clooney, ed. (New York: T and T Clark, 2010), 109-128.

${ }^{8}$ Visnu-Narayana, 137; R. Otto, "Ramanuja," Die Religion in Geschichte und Gegenwart, $2^{\text {nd }} . \mathrm{Ed}$. Vol. 4 (J.C.B. Mohr, 1930), 1693.

${ }^{9}$ Visnu-Narayana, 222-223; India's Religion of Grace, 15-16.

${ }^{10}$ India's Religion of Grace, 16-18.

${ }^{11}$ Otto, Visnu-Narayana, 218.

${ }^{12}$ India's Religion of Grace, $94 \mathrm{ff}$.

${ }^{13}$ Ibid., 94.

${ }^{14}$ Ibid., 93.

${ }^{15}$ Ibid., 94.

${ }^{16}$ Ibid., 94, 100.

${ }^{17}$ Francis X. Clooney, SJ, Hindu God, Christian God (New York: Oxford University Press, 2001). DOI: https://doi.org/10.1093/0195138546.001.0001 See Clooney's summary statement (p. 165): “While there may be some beliefs, practices, and creedal formulations justly recognized as unique to particular traditions, almost all of what counts as theological thinking is shared across religious boundaries."

${ }^{18}$ Ibid., 11.

19 Adam Hohenberger, Ramanuja: Ein Philosoph indischer Gottesmystik (Bonn, 1960. 141-142.

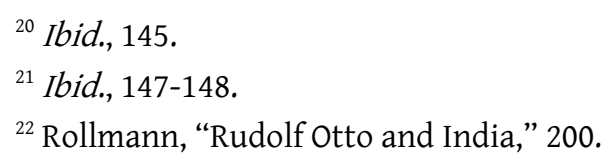

